Tropical Journal of Pharmaceutical Research September 2014; 13 (9): 1511-1514

ISSN: $1596-5996$ (print); 1596-9827 (electronic)

(c) Pharmacotherapy Group, Faculty of Pharmacy, University of Benin, Benin City, 300001 Nigeria.

All rights reserved.

Available online at http://www.tjpr.org

Original Research Article

http://dx.doi.org/10.4314/tjpr.v13i9.18

\title{
Spectrophotometric Methods for the Determination of Ketoconazole in Pharmaceutical Dosage Forms
}

\author{
SM Fraihat and KM Bahgat \\ Chemistry Department, Faculty of Science, Al Jouf University, Sakaka, Saudi Arabia
}

*For correspondence: Email: khaledelgarhi@yahoo.com; safwanf@yahoo.com

Received: 4 December 2013

Revised accepted: 17 July 2014

\begin{abstract}
Purpose: To develop simple, sensitive and economical methods for the determination of (KZ) in both pure samples and pharmaceutical formulations.

Methods: The first method $(A)$ was based on the oxidation of the studied drug by a known excess of cerium (IV) as an oxidizing agent and subsequent determination of unreacted oxidant by reacting it with indigo carmine (IN) dye. The second method (B) involved potassium permanganate as oxidant and methylene blue (MB) as dye. Spectrophotometry was used to determine the residual amount of the dyes by measuring the absorbance of the two dyes at 610 and $660 \mathrm{~nm}$, respectively. Comparison was made with the British Pharmacopoeia 1998 method.

Results: Linear calibration graphs were obtained at $4-30$ and $5-35 \mu \mathrm{g} / \mathrm{ml}$ for the two methods at 610 and $660 \mathrm{~nm}$, respectively. The regression equation was $Y=0.01 X+0.133,\left(R^{2}=0.996, R S D=78 \%\right.$ and limit of detection (LOD) of $\mu \mathrm{g} / \mathrm{ml}$ for method $A$. For the second method (B), it was $Y=0.008 X+$ $0.039,\left(R^{2}=0.995\right), R S D=0.95 \%$ and $L O D=2.3 \mu \mathrm{g} / \mathrm{ml}$. The proposed methods were successfully applied to the determination of $K Z$ in pharmaceutical formulations.

Conclusion: The results demonstrate that the methods are as accurate and reproducible as official methods.
\end{abstract}

Keywords: Ketoconazole, Spectrophotometry, Cerium, Permanganate, Indigo carmine, Methylene blue.

Tropical Journal of Pharmaceutical Research is indexed by Science Citation Index (SciSearch), Scopus, International Pharmaceutical Abstract, Chemical Abstracts, Embase, Index Copernicus, EBSCO, African Index Medicus, JournalSeek, Journal Citation Reports/Science Edition, Directory of Open Access Journals (DOAJ), African Journal Online, Bioline International, Open-J-Gate and Pharmacy Abstracts

\section{INTRODUCTION}

Ketoconazole (Fig 1 ) is chemically known as cis1-acetyl-4-[4-[[2-(2,4-dichlorophenyl)-2-(1Himidazole-1-ylmethyl)-1,3-dioxolan-4-

yl]methoxy]phenyl] piperazine.

The drug is a highly effective broad spectrum antifungal agent [1]. Different methods have been reported for its determination such as spectrophotometry [2-5], chromatography [6-8] and electrochemistry $[9,10]$. The oxidation of ketoconazole with cerium (Ce (IV)) has not been reported in literature before, therefore, a comprehensive investigation on the reaction conditions was found to be necessary.<smiles>CC(=O)N1CCN(c2ccc(OCC3COC(Cn4ccnc4)(c4ccc(Cl)cc4Cl)O3)cc2)CC1</smiles>

Fig 1: Structure of ketoconazole 
Standard chromatographic methods of ketoconazole generic assay require elaborate and sophisticated instrumentation and are of low sampling frequency.

Most of the spectrophotometric methods used for ketoconazole assay are based on either its oxidation or complexation with metal ions. Some of these methods require heating, extraction, long time for maximum color development and lengthy procedure as well as lacking sensitivity, specificity and wide dynamic ranges. The present method is simpler as it is based on indirect measurement of the drug concentration by using oxidation reaction of the drug using excess amount of the oxidant, then the remaining amount of the oxidant decolorizes certain dyes and the residual amount of the dye is determined by measuring its absorbance [11].

\section{EXPERIMENTAL}

\section{Apparatus}

A double-beam optical system SpectroScan 80D UV-VIS spectrophotometer with spectral bandwidth of $2 \mathrm{~nm}$, wavelength accuracy of \pm 0.3 $\mathrm{nm}$ (with automatic wavelength correction), wavelength range $(190-1100 \mathrm{~nm})$, wavelength reproducibility of $\pm 0.2 \mathrm{~nm}$ and a pair of $1-\mathrm{cm}$ matched quartz cells was used to measure absorbance of the resulting solution.

\section{Reagents and solutions}

All chemicals used were of analytical reagent grade and the solvents were spectroscopic grade. Double distilled water was used wherever required. Commercial tablets Nizoral ${ }^{\circledR}$ and Funazole $\AA$ labeled to contain $200 \mathrm{mg}$ ketoconazole per tablet was used.

The stock solution of $250 \mu \mathrm{g} / \mathrm{ml} \mathrm{KZ}$ was prepared in $1 \mathrm{M} \mathrm{H}_{2} \mathrm{SO}_{4}$ solution and was used to prepare different standard solutions. An aqueous solution of IN (Aldrich; $200 \mu \mathrm{g} / \mathrm{ml}$ ) and MB (Merck; 100 $\mu \mathrm{g} / \mathrm{ml}$ ) was prepared by dissolving the appropriate weight of the dye in a very small volume of water and then made up to $100 \mathrm{ml}$ in a calibrated flask.

The stock solutions of dyes were allowed to stand at room temperature for a few weeks without any significant decay. A stock solution of $1.0 \mu \mathrm{g} / \mathrm{ml} \mathrm{Ce}$ (IV) (Aldrich) was prepared by dissolving the appropriate weight in $0.5 \mathrm{M} \mathrm{H}_{2} \mathrm{SO}_{4}$ solution.
This solution was then standardized using sodium oxalate and stored in a dark.

A stock solution of $\mathrm{KMnO}_{4}$ solution $(600 \mu \mathrm{g} / \mathrm{ml})$ was prepared by dissolving appropriate amount in $200 \mathrm{ml}$ of water. The mixture is warmed for 30 min, cooled to room temperature then the final volume was adjusted to $250 \mathrm{ml}$.

\section{Optimisation of experimental conditions}

The optimum conditions for color development in each method were established by varying the parameters one at a time, keeping the others fixed and observing the effect produced on the absorbance of the colored species for methods A and $B$. In a series of experiments, the volumes of both dyes were varied using the constant concentrations of both $K Z$ and the selected oxidants, the results revealed that the optimum volumes of both indigo carmine and methylene Blue dyes were 2.5 and $2 \mathrm{ml}$ of the given concentrations respectively. For Methods $A$ and $B$, the effect of time on the absorbance values were investigated, the obtained results show no appreciable change after $8 \mathrm{~min}$, so it decided to measure the absorbance after $10 \mathrm{~min}$ from preparing the mixtures.

\section{Preparation of calibration curves}

Method A: Different volumes of standard KZ (250 $\mu \mathrm{g} / \mathrm{ml}$ ) solutions were pipetted into $10 \mathrm{ml}$ volumetric flasks, then $0.5 \mathrm{ml}$ of $\mathrm{Ce}(\mathrm{IV})$ (1.0 $\mu \mathrm{g} / \mathrm{ml}$ ) solution was added the mixture was then shaken and kept for $10 \mathrm{~min}$. after that $2.5 \mathrm{ml}$ of IN $(200 \mu \mathrm{g} / \mathrm{ml})$ was added, then the solution was made up to the $10.0 \mathrm{ml}$ with distilled water. The absorbance was then measured at $610 \mathrm{~nm}$ after $10 \mathrm{~min}$.

Method B: The same method above was performed except that $2 \mathrm{ml} \mathrm{KMnO}{ }_{4}(600 \mu \mathrm{g} / \mathrm{ml})$ and $2.0 \mathrm{ml}$ of MB $(100 \mu \mathrm{g} / \mathrm{ml})$ dye solutions were used, the absorbance of the final solutions were measured at $660 \mathrm{~nm}$.

\section{Procedures for drug formulations}

An amount of finely ground tablets equivalent to $5.0 \mathrm{mg}$ of $\mathrm{KZ}$ was accurately weighed, dissolved in appropriate amount of distilled water and transferred to a $100-\mathrm{ml}$ volumetric flask, the flask was sonicated for about $20 \mathrm{~min}$, finally the volume was made up to the mark. The content was kept aside for $5 \mathrm{~min}$, and filtered using 0.45 $\mu \mathrm{m}$ GHP filter paper. The first $(10 \mathrm{ml})$ portion of the filtrate was discarded and a suitable aliquot was used for the assay as described under general analytical procedure for the proposed 
method or using high performance liquid chromatography (HPLC) method.

\section{Statistical analysis}

The data were expressed as mean \pm SD and analysed statistically using Student t-test with the aid of Microsoft Excel 2003 software. Data were considered significantly different at $95 \%$ confidence limit.

\section{RESULTS}

Calibration curves for $\mathrm{KZ}$ determination using the proposed methods $A$ and $B$ were constructed by plotting absorbance vs. concentration using the optimized amounts of oxidants and dyes. The intercepts, slopes, and correlation coefficients were calculated using the method of least squares. Beer's law is obeyed over concentration ranges of $5-30 \mu \mathrm{g} / \mathrm{ml}$ for (Method A) and $5-35$ $\mu \mathrm{g} / \mathrm{ml}$ for (Method $B$ ). The mean molar absorptivity $(\varepsilon)$, limit of detection (LOD $=3 \mathrm{~s} / \mathrm{k}$ ) and limit of quantitation ( $\mathrm{LOQ}=10 \mathrm{~s} / \mathrm{k}$ ) were calculated, where $s$ is the standard deviation of replicate determinations in the absence of analyte under the same conditions as sample analysis and $\mathrm{k}$ is the slope. The LOD were 1.5 and $2.3 \mu \mathrm{g} / \mathrm{ml}$ using methods $A$ and $B$ respectively, these statistical results are shown in Table 1.

Table 1: Statistical analysis of calibration graphs and analytical data for the determination of ketoconazole using the proposed methods

\begin{tabular}{lcc}
\hline Parameter & Method A & Method B \\
\hline Wavelength $\lambda_{\max }(\mathrm{nm})$ & 660 & 610 \\
Regression data & & \\
Slope & 0.010 & 0.008 \\
Intercept & 0.133 & 0.039 \\
Correlation coefficient & 0.996 & 0.995 \\
$\left(r^{2}\right)$ & & \\
Beer's law limits & $5-30$ & $5-35$ \\
$(\mu \mathrm{g} / \mathrm{ml})$ & & \\
Sandell's sensitivity & 0.11 & 0.13 \\
$(\mu \mathrm{g} / \mathrm{ml})$ & & \\
$\mathrm{LOD}(\mu \mathrm{g} / \mathrm{ml})$ & 1.5 & 2.3 \\
$\mathrm{LOQ}(\mu \mathrm{g} / \mathrm{ml})$ & 4.5 & 6.9 \\
$\mathrm{RSD} \%$ & 0.78 & 0.95 \\
\hline
\end{tabular}

\section{Application to drug formulation}

The suggested method were applied successfully for the determination of ketoconazole in commercial tablets from local market, Statistical comparison of the accuracy and precision of the proposed methods with an HPLC method [12] was performed using student's t-tests at a $95 \%$ confidence level. The t-values did not exceed the theoretical values; there is no significant difference in accuracy or precision between the proposed and the official method as shown in Table 2.

\section{DISCUSSION}

Ketoconazole undergoes fast oxidation reaction with strong oxidizing agents. It also shows no absorption band in the visible region which makes it difficult to be determined directly using simple spectrophotometric methods. So we suggest two simple and inexpensive procedures for the determination of $K Z$ in pure and pharmaceutical preparations based on treating $\mathrm{KZ}$ solutions with an excess amount of oxidizing agent, then the residual amount of oxidant bleaches certain dye, so that the remaining amount of dye can be determined spectrophotometrically. As a result, a proportional increase in the absorbance for the two dyes is observed with increasing concentration of $\mathrm{KZ}$.

In method $\mathrm{A}, \mathrm{Ce}$ (IV) in sulfuric acid was used as oxidizing agent and IN was used as a dye; the absorbance was measured at $610 \mathrm{~nm}$. In method $B$, potassium permanganate was used as oxidizing agent and $\mathrm{MB}$ was used as the dye which has a maximum absorption at $660 \mathrm{~nm}$. Preliminary experiments were performed to fix the upper concentrations of the oxidants that could be used to maintain excess amounts. A $\mathrm{Ce}(\mathrm{IV})$ concentration of $8.0 \mu \mathrm{g} / \mathrm{ml}$ was found to bleach the color due to $5 \mu \mathrm{g} / \mathrm{ml}$ IN whereas 34.0 $\mu \mathrm{g} / \mathrm{ml} \mathrm{KMnO}_{4}$ was required to destroy the blue color of MB.

Table 2: Comparison between the proposed method and the standard method

\begin{tabular}{llllll}
\hline Drug & \multicolumn{2}{c}{ Proposed method } & \multicolumn{2}{c}{ Standard method } & t-value \\
\cline { 2 - 5 } & $\begin{array}{l}\text { Amount taken } \\
(\boldsymbol{\mu g} / \mathbf{m I})\end{array}$ & $\begin{array}{l}\text { Recovery } \\
\boldsymbol{R S D} \%\end{array}$ & $\begin{array}{l}\text { Amount taken } \\
(\boldsymbol{\mu g} / \mathbf{m I})\end{array}$ & $\begin{array}{l}\text { Recovery } \mathbf{~} \\
\boldsymbol{R S D} \%\end{array}$ & \\
\cline { 2 - 5 } Method A & 25 & $97 \% \pm 8$ & 15 & $98 \% \pm 2$ & 0.85 \\
Method B & 25 & $98 \% \pm 8$ & 50 & $97 \% \pm 2$ & 0.56 \\
\hline
\end{tabular}

Tabulated student $t$-value at $95 \%$ confidence level and 6 degrees of freedom is (2.44) 
For both methods, the absorbance was monitored at $25{ }^{\circ} \mathrm{C}$ with time which showed that the oxidation reaction is fast and complete in 5 min, and contact times up to 8 min had no effect on the absorbance of dyes.

\section{CONCLUSION}

The developed methods are simple, rapid, and accurate, and also compare well with standard methods.

\section{REFERENCES}

1. Delgado JN, Remers WA, Text book of Organic Medical and Pharmaceutical Chemistry. Wiley, New York, 1991.

2. Nairman A, Yasser S. Investigation of Ketoconazole Copper(II) and Cobalt(II) Complexes and Their Spectrophotometric Applications. J. AOAC Int, 2001; 84: 563-568.

3. El-Shabouri SR, Emara KM, Khashaba PY, Mohamed AM. Charge-transfer complexation for spectrophotometric assay of certain imidazole antifungal drugs. Anal. Lett 1998; 31: 1367-1385.

4. Sane RT, Tendolkar RV, GangalLadae DP, Kothurkar RM. An extractive colorimetric method for the determination of ketoconazole for pharmaceutical preparations. Indian J. Pharm. Sci, 1988; 50: 347348.
5. Farhadi K, Maleki $R$. Triiodide ion and alizarin red $S$ as two new reagents for the determination of clotrimazole and ketoconazole. J. Pharm. Biomed. Anal, 2002; 30: 1023-1033.

6. Kedor-Hackmann ERM, Nery MMF, Sanntoro MIRM. Determination of ketoconazole in pharmaceuticals preparations by ultraviolet spectrophotometry and high performance liquid chromatography. Anal. Lett, 1994; 27: 363-376.

7. Low AS, Wangboonskul J. An HPLC assay for the determination of ketoconazole in common pharmaceutical preparations. Analyst 1999; 124: 1589-1593.

8. Abdel-Moety EM, Khattab Fl, Kelani KM, AbouAl-Alamein AM. Chromatographic determination of clotrimazole, ketoconazole and fluconazole in pharmaceutical formulations. Farmaco, 2002; 57: 931-938.

9. Fijalek Z, Chodkowski J, Waraowna M. Polarographic examination of drugs derived from imidazol, Clotrimazole and ketoconazole. Acta Pol. Pharm, 1992; 49: 1-5.

10. Shamsipur M, Farhadi KH. Adsorptive stripping voltammetric determination of ketoconazole in pharmaceutical preparations and urine using carbon paste electrodes. Analyst 2000; 125: 1639-1643.

11. Fraihat S, Khatib HS. Indirect Spectrophotometric Determination of Tolterodine Tartrate in Pure and Pharmaceutical Preparation. Asian J Chem 2013; 25: 1887-1890.

12. British Pharmacopoeia, HM Stationary Office, London, 1998. 